\title{
https://dx.doi.org/10.4314/iijikm.v10i2.5 \\ Influence of ICT Skills on Library Information Resources Utilisation by Undergraduates in Two Universities in South-West, Nigeria
}

\author{
Oresiri Jamogha \\ Babs Fafunwa Library, Adeyemi College of Education, Ondo \\ oresiriakpotor@yahoo.com \\ Ejiro Jamogha \\ Hezekiah Oluwasanmi Library, Obafemi Awolowo University, Ile-Ife \\ ejamogha@oauife.edu.ng \\ Lucky Stephen Godwin \\ Tekena Tamuno Library, Redeemer's University, Ede, Osun State, Nigeria \\ godwins@run.edu.ng
}

\begin{abstract}
The study investigated the influence of ICT skills on library information resources utilisation by undergraduates in two universities in South-west, Nigeria. Descriptive survey research was adopted for the study. From a population of 32,419 undergraduates in the University of Ibadan and the Obafemi Awolowo University, Ile-Ife, a multi-stage sampling technique was used to select 407 respondents. Questionnaire was the instrument used for data collection. Four hundred and seven copies of questionnaires were administered to respondents, however, 377 were found useful for the analysis. Research questions were answered using descriptive statistics such as frequency, percentage and mean distribution, while the research hypothesis was analysed, using Pearson's correlation coefficient and was tested at a 0.05 level of significance. Findings of the study showed that ICT skills possessed by the undergraduates were high. The extent of library information resources utilisation by undergraduates was generally low; however reference materials and monographs/textbooks were highly utilised. The result also revealed that there was significant positive correlation $\left(r=.383^{* *} ; \mathrm{p}<0.05\right)$ between ICT skills and library information resources utilisation. Thus, it was recommended that library management should leveraged on the ICT skill possessed by undergraduates by adopting and implementing ICTs in the provision of library services that would enhance ICT skills and facilitate the utilisation of library information resources by undergraduate.
\end{abstract}

Keywords: ICT Skills, Library Information Resources, library resources, utilisation

\section{Introduction}

Information resources are one of the

products that define libraries in terms of

what they stand for. In a normal situation,

the types of information resources in a

library are relatively directed at the category

of users they are expected to serve. Library

information resources are the information bearing materials that are either in print or non-print format. They include CD-ROM, textbooks, journals, OPAC, online databases, serials, Internet resources among others. In a university, the information resources housed or provided by the university library are meant to support the teaching, learning and research activities of 
Influence of ICT skills on library information resources utilization by undergraduates in two universities in south west, Nigeria

the university, and undergraduates constitute a greater percentage of students in most universities. This was reiterated by Maxwell (2018) who opined that in any discipline, the backbone of teaching, learning and research is information resources. Thus, beyond the classroom, undergraduates are expected to utilise information resources provided by the library in complementing classroom instructions, especially in this age of globalisation where ICTs facilitate quick and easy access to a wide range of information resources worldwide.

The provision and use of ICT is part and parcel of the entire system; including undergraduates, information professionals, staff, and researchers. It is one thing to recognise the importance of ICTs and another to know if they are effectively used by students. If ICTs were to be effectively applied directly or indirectly on the utilisation of information resources, skills are required. In this regard, Israel and Edesiri (2013) stated that ICT skill is one essential requirement for one to operate in the knowledge society of the 21 st Century.

Ukaegbu and Wegwu (2019) citing Quadri (2012) described ICT skills as the abilities for the collection, effective processing, storing, transmitting and the dissemination of information which enables the use of computers and related technologies to meet personal academic and labour market objectives. ICT skills of a student is a relative measure of the student's capacity to make appropriate use of ICT for educational and learning purposes, this is because, ICT skills are required to critically evaluate information content and explore it effectively, as well as understanding the technological infrastructure on which information transmission is based (Oliver \& Tower, 2000).

There is every tendency that the capacity of users to exploit ICT related information resources in a university library will depend on the level of their skills, education and mastery of the technologies involved. Thus, this study investigates the influence of ICT skills on library information resources utilisation by undergraduates in two universities in SouthWest, Nigeria.

\section{Statement of the Problem}

The main problem of this study is underutilisation of library information resources by undergraduates. The role of the university library is to provide information resources such as textbooks, Internet resources, OPAC, online databases, CDROM among others, that will support teaching curriculum and to assist students in 
Influence of ICT skills on library information resources utilization by undergraduates in two universities in south west, Nigeria

complementing classroom instructions for academic excellence. The university libraries under study are making effort to regularly update their information resources through acquisition of print materials, electronic resources, and subscription to online databases as well as providing access to these information resources through the library catalogue/OPAC as well as Internet access in the library. However, observation has shown that students do not make effective use of the information resources in these libraries. This could be as a result of the poor ICT skills of the students, thus, this study examines the influence of ICT skills on library information resources utilisation by undergraduates in two universities in South-West, Nigeria

\section{Objectives of the Study}

The main objective of this study is to investigate the influence of ICT skills on library information resources utilisation by undergraduates in two universities in SouthWest, Nigeria. While the specific objectives of this study are to:

i. determine ICT skills of undergraduates in two universities in South-west, Nigeria;

ii. determine the extent of library information resources utilisation by undergraduates in the universities; and

iii. ascertain the influence of ICT skills on library information resources utilisation by undergraduates in the two universities in South-west, Nigeria.

\section{Research Questions}

In line with the stated objectives of the study, the following research questions were raised to guide the study:

1. What are the ICT skills possessed by the undergraduates in two universities in South-west, Nigeria?

2. What is the extent of library information resources utilisation by undergraduates in the two universities?

\section{Hypothesis}

The null hypothesis stated and tested at a 0.05 level of significance in this study is:

There is no significant relationship between ICT skills and library information resources utilisation among undergraduates in two universities in South-west, Nigeria.

\section{Literature Review}

Information resources are the major product by which library can meet the information needs of its users. Iwhiwhu and Okorodudu (2012) suggested that a library may meet 
Influence of ICT skills on library information resources utilization by undergraduates in two universities in south west, Nigeria

user's information needs by acquiring, organising and making available relevant information resources backed by appropriate facilities and delivered by means best known to them, which could be manual or through information and Communication Technologies (ICTs). According to Quadri, Adetimirin and Idowu (2014), undergraduates are expected to read further after class instructions to collect relevant information for class assignments, seminars, term papers, dissertations, theses and projects.

Ishola and Obadare (2014) examined the availability, access to and level of use of academic library information resources of selected libraries in South-western Nigeria. The objectives of the study were to determine the extent of access to information resources; find out the frequency of use and to determine the barriers to the use of information resources. The major findings were that there is high level of availability and accessibility of information resources in the selected Nigeria universities studied. Result also revealed that most of the students used information resources daily.

Onyekweodiri and Agbo (2015) investigated the utilisation of library resources by veterinary medicine students in two federal universities in South-East of Nigeria. The result obtained from the study revealed that library information resources required by the students, ranges from newspapers, magazines, current awareness services, journals, online resources related to veterinary medicine to many more. Egbunu, Usman and Usman (2013) examined the availability and utilisation of information resources and services by academic staff in University of Abuja. The results revealed that the availability of library resources was fairly adequate and the library was underutilised.

Similarly, Oluwatobi, Ehioghae, Aluko-Arowolo and Onasote (2014) conducted a study on "the utilisation of library resources for effective research output among postgraduate students in Adventist University of Africa”. They found that the most frequently used library materials is the online database, dictionaries, books and encyclopedia which are used daily, while the least used material was CDROM database. Furthermore, respondents in this study affirmed that the available library resources have a very low impact on their respective research work.

Abosede and Ibikunle (2011) conducted a study on "determinants of library use among students of agriculture: a 
Influence of ICT skills on library information resources utilization by undergraduates in two universities in south west, Nigeria

case study of Lagos State Polytechnic". It was revealed that as there were electronic resources and Internet availabliability as alternatives to library use, students' use of the library decreases.

Attwell (2005) described ICT skills as those skills related to the use of computers, and other technologies such as the ability to transmit stored information through fixed line networks.

Lamanauska and Vilkonis (2007) asserted that ICT skills include all the technical abilities to use digital technology, communication tools, and/or networks to define information need, access, manage, integrate and evaluate information, create new information or knowledge and be able to communicate this information to others

Katz and Macklin (2010) revealed in a study "information communication technology: integration and assessment in higher education" that despite coming of age with the Internet, many college students lacked ICT literacy skills such as locating evaluating and communicating information necessary to navigate and use information resources. In Romania, Coravu (2010) noted that empiric observation of fresh students at Carol Central University Library of Buchrest showed that their information behaviours is oriented towards the use of
Internet resources because they have been exposed to ICT before entering the university.

In Malaysia, Ali, Abu-Hassan, Yusuf, David and Juoff (2010) did an investigation on information literacy skills of engineering students. The respondents in the study were diploma-engineering students who had undergone at least three semesters at a Malaysian college. The result of the study revealed that respondents seriously lacked the necessary skills to evaluate internet information, to identify the most efficient search strategy, to use scholarly resources, and to use information ethically. It was also revealed that most scholarly resources used were books in print format, while most non-scholarly resources referred to were electronic format. The implication of the study is that students' use of electronic scholarly resources for their course assignments was minimal.

Hossain and Sormunen (2019) conducted a study on "ICT skills of Library Information Science (LIS) students in Bangladesh, and found that the selfestimated ICT skills of the students was good. Similarly, Otolo, Saibakumo and Urhibo (2018) in a study "impact of ICT skills on the use of electronic resources by undergraduate students in Nigerian 
Influence of ICT skills on library information resources utilization by undergraduates in two universities in south west, Nigeria

university libraries" found that ICT skill among undergraduates in Nigerian universities was high.

Sinha (2012) in an evaluative study Internet literacy skills and Internet usage patterns to access e-resources by Assam University Library Users, found that out of 319 respondents 257 respondents representing $81 \%$ of library users were Internet and ICT literate. Similarly, in Kenya, Kimani (2014) in a study "information literacy skills among incoming first-year undergraduate students at the Catholic University of Eastern Africa in Kenya found that first year undergraduates in Catholic University of Eastern Africa, Kenya possess computer skills in applications such as the use of the Internet and its applications (e.g. social networking sites and World Wide Web) as well as wordprocessing applications such as Microsoft Office and statistical applications such as SPSS. However, findings revealed the lack of skill in searching for information.

Gakibayo, Ikoja-Odongo and OkelloObura (2013) conducted a study on "electronic information resources utilisation by students in Mbarara University Library. They found that the utilisation of e-resources was affected by lack of computer skills and information literacy skill. Similarly,
Rosenita and Zainab (2013) in an exploratory study which focus on identifying the usage pattern of e-books especially on how, when, where and why undergraduates at the Faculty of Computer Science and Information Technology (FCSIT), University of Malaya (UM), Kuala Lumpur, use or do not use the e-resources services provided by the University of Malaya, Library, found that the students are heavy users of the Internet, and that they rate themselves as skilled in the use of ICT and have positive attitude towards the services, however, the level of e-resources use is still very low. However, Otolo, Saibakumo and Urhibo (2018) observed that ICT skills of undergraduates enable them to effectively utilise information resources.

From the foregoing literature, it could be inferred that the ICT skills among undergraduates that is necessary for the effective utilisation of library information resources is low, and there are traces of underutilisation of information resources in libraries. It is noteworthy that none of the literature reviewed discussed the influence of ICT skills on library and information resources utilisation in two universities in South-west Nigeria. It is this gap that this study intends to fill. 
Influence of ICT skills on library information resources utilization by undergraduates in two universities in south west, Nigeria

\section{Methodology}

Descriptive research survey was adopted for this study. Multi-stage sampling technique was used to select 407 undergraduates from a population of 32,419 in the University of Ibadan and the Obafemi Awolowo University, Ile-Ife. The first stage involved selecting three similar faculties in both universities; the second stage involved selecting three departments in each of the faculties using balloting technique; the third stage involved selecting all undergraduates who are in 100 to 400 levels. The last stage involved determining the sample size of the study. Gay and Airasian (2003) in "educational research: competencies for analysis and application" stated that one rule of thumb for determining an adequate sample size for descriptive research is that it should consist of 10 to $20 \%$ of the population under study. Based on the submission by Gay and Airasian (2003) a sampling fraction of $10 \%$ was used to determine the sample size of the study, given a total of 407 respondents.

The instrument for data collection was questionnaire. Research questions were answered using descriptive statistics such as frequencies and mean distribution. While the hypothesis was analysed using Pearson's
Correlation Coefficient and tested at a 0.05 level of significance.

\section{Data Analysis and Interpretation of}

\section{Findings}

A total of four hundred and seven (407) copies of questionnaire were administered to respondents in the University of Ibadan (UI) and Obafemi Awolowo University (OAU), Ile-Ife, with each having 176 and 231 copies of the questionnaire respectively. However, 162 and 215 copies of the questionnaire from the respondents in UI and OAU respectively, were duly filled and returned giving a total of three hundred and seventyseven (377), thus giving a 92.6\% response rate from the respondents. Hence, 377 copies of the questionnaire were used for data analysis.

Table 1: Distribution of respondents by Faculties

\begin{tabular}{|c|c|c|}
\hline Faculties & Frequency & Percentage \\
\hline Arts & 99 & $26.3 \%$ \\
\hline Science & 143 & $37.9 \%$ \\
\hline Social Science & 135 & $35.8 \%$ \\
\hline Total & 377 & 100 \\
\hline
\end{tabular}

Table 1, shows that most of the respondents $143(37.9 \%)$ were science students, while 99(26.3\%) were Arts students.

Table 2: Level of study

\begin{tabular}{|c|c|c|}
\hline Level & Frequency & Percentage \\
\hline 100 & 89 & $23.6 \%$ \\
\hline 200 & 82 & $21.8 \%$ \\
\hline 300 & 101 & $26.8 \%$ \\
\hline
\end{tabular}


Influence of ICT skills on library information resources utilization by undergraduates in two universities in south west, Nigeria

\begin{tabular}{|c|c|c|}
400 & 105 & $27.8 \%$ \\
\hline Total & 377 & 100 \\
\hline
\end{tabular}

Table 2 shows that most of the respondents $105(27.8 \%)$ were in 400level of study, while, $82(21.8 \%)$ of the respondents were in 200level of study.

Research question 1: What are the ICT skills possessed by undergraduates in two universities in South-west, Nigeria? The
Table 3: Gender of respondents

\begin{tabular}{|c|c|c|}
\hline Sex & Frequency & Percentage \\
\hline Male & 218 & $57.8 \%$ \\
\hline Female & 159 & $42.2 \%$ \\
\hline Total & 377 & 100 \\
\hline
\end{tabular}

Table 3 shows that, $218(57.8 \%)$ of the respondents were males while, 159(42.2\%) respondents fere females.

data on the ICT skills possessed by undergraduates in two universities in Southwest, Nigeria is presented in Table 4.

Table 4: ICT skills possessed by undergraduates in two universities in South-west, Nigeria.

\begin{tabular}{|c|c|c|c|c|c|c|}
\hline S/NO & ICT Skills & SD & D & A & SA & Mean \\
\hline 1 & $\begin{array}{l}\text { I have the ability to start up, } \log \text { on, and shut down a } \\
\text { computer system. }\end{array}$ & 35 & 16 & 56 & 270 & 3.49 \\
\hline 2 & $\begin{array}{l}\text { I can download information materials from databases made } \\
\text { accessible by the library. }\end{array}$ & 42 & 25 & 20 & 290 & 3.48 \\
\hline 3 & I can use bookmark to record a useful WWW address. & 20 & 31 & 234 & 92 & 3.06 \\
\hline 4 & $\begin{array}{l}\text { I have the ability to copy and paste information from WWW } \\
\text { search to your document. }\end{array}$ & 27 & 20 & 252 & 78 & 3.01 \\
\hline 5 & I can use known WWW address to find useful information. & 30 & 21 & 248 & 78 & 2.99 \\
\hline 6 & $\begin{array}{l}\text { I can send and open an attachment from an email, using a } \\
\text { computer email program. }\end{array}$ & 32 & 19 & 249 & 77 & 2.98 \\
\hline 7 & I can use word processing application to type and edit files. & 34 & 17 & 248 & 78 & 2.98 \\
\hline 8 & $\begin{array}{l}\text { I can find, use and present information whether in text, image } \\
\text { and etcetera. }\end{array}$ & 30 & 21 & 256 & 70 & 2.97 \\
\hline 9 & $\begin{array}{l}\text { I have the ability to use search engines to search for } \\
\text { information e.g. Yahoo, Google, MSN. }\end{array}$ & 40 & 11 & 251 & 75 & 2.96 \\
\hline 10 & I can search and apply information. & 37 & 14 & 257 & 69 & 2.95 \\
\hline 11 & $\begin{array}{l}\text { I can use information from the WWW in projects and /or } \\
\text { assignment. }\end{array}$ & 46 & 5 & 250 & 76 & 2.94 \\
\hline 12 & $\begin{array}{l}\text { I can access and use the information retrieved from my } \\
\text { library's OPAC (Online Public Access Catalogue). }\end{array}$ & 39 & 12 & 258 & 68 & 2.94 \\
\hline 13 & I have the ability to backup computer files. & 44 & 48 & 217 & 68 & 2.82 \\
\hline 14 & $\begin{array}{l}\text { I can Use keywords or phrases to search for information on } \\
\text { the WWW. }\end{array}$ & 51 & 40 & 255 & 31 & 2.71 \\
\hline
\end{tabular}


Influence of ICT skills on library information resources utilization by undergraduates in two universities in south west, Nigeria

\begin{tabular}{|r|l|r|r|r|r|r|}
15 & $\begin{array}{l}\text { I have the ability to copy files from one location into another } \\
\text { location. }\end{array}$ & 15 & 247 & 37 & 78 & 2.47 \\
\hline 16 & I can access library resources on the Web. & 86 & 114 & 142 & 35 & 2.33 \\
\hline 17 & I can use advance search techniques (Boolean operators). & 28 & 251 & 52 & 46 & 2.31 \\
\hline 18 & $\begin{array}{l}\text { I can use my library's computer catalogue to search for } \\
\text { information materials in the library. }\end{array}$ & 51 & 248 & 31 & 47 & 2.20 \\
\hline 19 & I have the ability to identify and use computer icons. & 200 & 6 & 69 & 102 & 2.19 \\
\hline & \multicolumn{3}{|c|}{ Aggregate mean= 2.83, Criterion mean= 2.5 } \\
\cline { 2 - 6 } & \multicolumn{3}{|l|}{$\mathbf{3 7 7}$}
\end{tabular}

Note: $N=$ Count, $S A=$ Strongly Agree, $A=$ Agree, Disagree $=D, S D=$ Strongly Disagree

The ICT skills possessed by the library" (mean $=2.20$ ), "I can use advance undergraduates as revealed in Table 4 are; "I have the ability to start up, log on, and shut down a computer system" (mean $=3.49)$, followed by "I can download information materials from databases made accessible by the library" (mean $=3.48)$, "I can use bookmark to record a useful WWW address" ( mean $=3.06)$, "I have the ability to copy and paste information from WWW search to your document" $($ mean $=3.01)$, "I can use known WWW address to find useful information" (mean = 2.99). While the least ICT skills possessed by the undergraduates are "I have the ability to identify and use computer icons" (mean $=2.19)$, followed by 'I can use my library's computer catalogue to search for information materials in the search techniques (Boolean operators)" (mean $=2.31)$, "I can access library resources on the Web" $($ mean $=2.33)$ and "I have the ability to copy files from one location into another location" (mean = 2.47). Hence, the ICT skills possessed by the undergraduates include: start-up/log on/shutdown computer systems, downloading information resources from databases, bookmarking web addresses and easily finding information using the WWW. Since Table 4 showed that the aggregate mean of 2.83 is greater than the criterion mean of 2.5, it can be inferred that the ICT skills possessed by the undergraduates in the two universities is high 
Influence of ICT skills on library information resources utilization by undergraduates in two universities in south west, Nigeria

Research question 2: What is the extent of library information resources utilisation by undergraduates in the two universities?
The data on the extent of library information resources utilisation by undergraduates in two universities in South-west, Nigeria is presented in Table 5.

Table 5: Extent of library information resources utilisation by undergraduates in two universities in South-west, Nigeria

\begin{tabular}{|r|l|r|r|r|r|r|}
\hline S/NO & Library Information Resources Utilisation & $\begin{array}{r}\text { Very } \\
\text { Low } \\
\text { Use }\end{array}$ & $\begin{array}{c}\text { Low } \\
\text { Use }\end{array}$ & $\begin{array}{c}\text { Highly } \\
\text { Used }\end{array}$ & $\begin{array}{c}\text { Very } \\
\text { Highly } \\
\text { Used }\end{array}$ & Mean \\
\hline 1 & 70 & 55 & 54 & 198 & 3.28 \\
& $\begin{array}{l}\text { Reference materials (e.g dictionaries, } \\
\text { encyclopedia) }\end{array}$ & 48 & 44 & 48 & 237 & 3.26 \\
\hline 2 & Monographs/textbooks & 73 & 46 & 27 & 231 & 3.10 \\
\hline 3 & Printed Maps & 42 & 59 & 227 & 49 & 2.75 \\
\hline 4 & Charts & 31 & 70 & 246 & 30 & 2.73 \\
\hline 5 & Journals & 70 & 34 & 233 & 40 & 2.64 \\
\hline 6 & Newspaper/magazines & 109 & 199 & 40 & 29 & 1.97 \\
\hline 7 & Pamphlets & 238 & 20 & 27 & 92 & 1.93 \\
\hline 8 & Photographs & 106 & 235 & 11 & 25 & 1.88 \\
\hline 9 & Government publications & 234 & 48 & 14 & 81 & 1.85 \\
\hline 10 & Realia & 196 & 139 & 30 & 12 & 1.62 \\
\hline 11 & Theses/dissertations & 263 & 36 & 37 & 41 & 1.62 \\
\hline 12 & $\begin{array}{l}\text { Electronic Information Resources (e.g e- } \\
\text { journals, e-books and so on) }\end{array}$ Aggregate mean= 2.39, Criterion mean = 2.5 & & \\
\hline \multirow{2}{*}{$\mathbf{N}=\mathbf{3 7 7}$} & & & \\
\hline
\end{tabular}

Table 5 shows that the library information resources with a high extent of utilisation as indicated by the respondents are Reference materials (e.g dictionaries, encyclopedia) (mean $=3.28)$, followed by Monographs/textbooks (mean $=3.26)$, Printed Maps $($ mean $=3.10)$, Charts $($ mean $=$ 2.75), Journals (mean $=2.73$ ) and Newspaper/magazines $($ mean $=2.64)$. While the library information resources with the least extent of use are electronic information resources (e.g e-journals, e-books and so on) $($ mean $=1.62)$, Theses $/$ dissertations $($ mean $=$ $1.62)$, realia $($ mean $=1.85)$, government publication $($ mean $=1.88)$, Photographs $($ mean $=1.93)$ and Pamphlets $($ mean $=1.97)$. Since Table 5 showed that the aggregate mean of 2.39 is greater than the criterion 
Influence of ICT skills on library information resources utilization by undergraduates in two universities in south west, Nigeria

mean of 2.5 , it can be inferred that the extent of library information resources utilisation by undergraduates in the two universities in South-west, Nigeria, is low.

Hypothesis: There is no significant relationship between ICT skills and library information resources utilisation among

Table 6: Correlation showing the relationship between ICT skills and library information resources utilisation in two universities in South-west, Nigeria.

\begin{tabular}{|l|l|l|l|l|l|l|l|l|}
\hline \multicolumn{2}{|c|}{ Group } & N & Mean & Std. Dev. & r-cal & Df & Sig. P & Remark \\
\hline ICT skills & 377 & 53.79 & 14.52 & & & & \\
\hline & & & & $383^{* *}$ & 376 & 0.00 & Significant \\
\hline $\begin{array}{l}\text { Library information resources } \\
\text { utilisation }\end{array}$ & 377 & 28.36 & 4.97 & & & & \\
\hline
\end{tabular}

Significant at $\mathrm{p}<0.05$

Table 6, shows that there is significant positive correlation $\left(\mathrm{r}=.383^{* *} ; \mathrm{p}<0.05\right)$ between ICT skills and library information resources utilisation among undergraduates in two universities in South-west, Nigeria. This implies that, the higher the ICT skills possessed by undergraduates, the more they will utilise library information resources. Therefore, the null hypothesis is rejected.

\section{Discussion of Findings}

The findings of this study showed that ICT skills (start-up/logon/shutdown computer systems, downloading information resources from databases, bookmarking web addresses and easily finding information using the WWW) possessed by the undergraduates in the two universities studied was high. This is undergraduates in two universities in Southwest, Nigeria. Data on the relationship between ICT skills and library information resources utilisation among undergraduates in two universities in South-west, Nigeria is presented in Table 6. 
Influence of ICT skills on library information resources utilization by undergraduates in two universities in south west, Nigeria

Additionally, the study revealed that the extent to which library information resources were utilised by the undergraduates was generally low. This was evident in the low use of electronic information resources, theses, government publications and photographs, although monographs and newspapers had a high use. This was supported by the study of Egbunu, Usman and Usman (2013) who examined the availability and utilisation of information resources and services by academic staff in University of Abuja. The results revealed that the availability of library resources was fairly adequate and the library was underutilised. Similarly, Rosenita and Zainab (2013) found that the use of library resources was generally low.

It was also revealed that ICT skills have positive effect on library information resources utilisation by undergraduates in the two universities. This was supported by Israel and Edesiri (2014) who affirmed that one essential requirement for one to operate in the knowledge society of the 21st Century is ICT skills. This is in line with the findings of the study conducted by Gakibayo, IkojaOdongo and Okello-Obura (2013) which revealed that the utilisation of e-resources was negatively affected by lack of computer skills and information literacy skill. In affirmation, Otolo, Saibakumo and Urhibo (2018) observed that ICT skills of undergraduates enable them to effectively utilise information resources.

\section{Conclusion and Recommendations}

ICT skills of undergraduates has a positive influence on the utilisation of library information resources, especially when the use of such resources requires the application of ICTs either directly (that is, the resources use is dependent on ICT application, for example, the access and download of a journal article from an online database) or indirectly (that is, ICT may be required as a tool to facilitate access to such information resources, for example, the use of Online Public Access Catalogue (OPAC) to access books on the library shelves). Although it was found that the ICT skills of the respondents were high, the utilisation of library information resources was low, and thus, the following recommendations were given:

1. Since the ICT skills of the respondents were high, it should be sustained by library management through the provision of ICT facilities (for example, bluetooth and wireless network enabled devices) in the library to curb the problem associated with point to 
Influence of ICT skills on library information resources utilization by undergraduates in two universities in south west, Nigeria

$\begin{array}{ll}\text { point connections, thereby facilitate the use information } \\ \text { encouraging more users of library } & \text { resources in the library. }\end{array}$
information resources and consequently enhancing the respondents ICT skills.

2. The utilisation of library information resources was low, hence, library management should leverage on the ICT skills possessed by the undergraduates, by adopting and implementing ICT in the provision of services that would

3. The library management should make it a rule that once a new ICT technology for accessing information resources is adopted in the library, a training programme must be organised for the library users, and manual on how to use such technology should be provided to guide the users. 
Influence of ICT skills on library information resources utilization by undergraduates in two universities in south west, Nigeria

\section{References}

Abosede A.T. \& Ibikunle O.O. (2011). Determinants of library use among students of agriculture: a case study of Lagos State Polytechnic. Library Philosophy and Practice (e-journal) Paper 5 lavailable at

http://digitalcommons.unl.edu/libphilprac/52 $\underline{1}$

Ali, R, Abu-Hassan N., Yusuf M.D., David M. \& Juoff K. 2010.Information literacy skills of engineering students.IJRRAS, 5(3): 264-270.

Attwell J. (2005). Mobile technologies and learning.Learning and skills development agency. UK: State University of New York Press

Coravu R. (2010). Library literacy; the step before information literacy.First International Conference in Romania on Information Literacy, Sibiu, Romania, 22-23 April, 2010.

Egbunu J.A., Usman A. \& Usman A. (2013) examined the availability and utilisation of information resources and services by academic staff in University of Abuja. African Journals Online (AJOL):Information Technologist, 10(2).

Gakibayo A., Ikoja-Odongo J.R. \& OkelloObura C. (2013).Electronic information resources utilisation by students in Mbara University Library. Library Philosophy and Practice. (E-journal) Paper 869. Available at $\operatorname{prac} / 869$ http://digitalcommons.unl.edu/libphil

Gay, L. R., \& Airasian, P. (2003).

Educational Research: Competencies for Analysis and Applications (7th ed.). Upper Saddle River, NJ: Merrill Prentice Hall.
Hossain, M.A. \& Sormunen, E. (2019). ICT skills of Library Information Science (LIS) students in Bangladesh. International Information \& Library Review, 15(1):235299

Ishola B.C. \& Obadare O.S. (2014). Availability, access to level of use of academic library information resources: study of selected academic libraries in South-Western Nigeria. Journal of Educational Practice, 5(28):20-33

Israel O. \& Edesiri E. (2013). ICT.skills and internet usage among library and information science students in Delta and Edo States, Nigeria; International Journal of Library and Information Science.

Iwhiwhu B.E. \& Okorodudu P.O. (2012). Public library information resources, facilities and services: user satisfaction with the Edo State Central Library, Benin City, Nigeria. Library and Philosophy and Practice, paper 747

Katz I.R. \& Macklin A. S. (2010). Information and communication literacy: integration and assessment in higher education. Systems, Cybernetics and Informatics. 5(4): 50-55.

Kimani H. N. (2014). Information literacy skills among incoming first-year undergraduate students at the Catholic University of Eastern Africa in Kenya.Retrieved from http://hdl.handle.net/10500/14461.

Lamanauskas V. \& Vikonis R. (2007). Information communication technologies in natural science education: situational analysis and prospects in Baltic countries. Journal of Baltic Science Education, 6.2:35-49 
Influence of ICT skills on library information resources utilization by undergraduates in two universities in south west, Nigeria

Lowe G. \& McAuley J. (2002). Adult literacy and life skills survey, information and communication technology literacy assessment framework 1-14 Available at www.ets.org/all/ictl2ndframework.p

df

Maxwell, C.E.O. (2018). Print information resources utilization for social science research in state universities in North Central Zone, Nigeria. The Information Technologist:an International Journal Information and Communication Technology (ICT),15(1):18-35

Oliver, R \& Towers S (2000).Benchmarking ICT literacy in tertiary learning settings. Available at

http://www.ascilite.org.au/conferences/coffs 00/papers/ron_Oliver.pdf

Oluwatobi O.I., Ehioghae M. AlukoArowolo T.K. \& Onasote A.O. (2014). Utilisation of library resources for effective research output among postgraduate students in Adventist University of Africa. Global Journal of Human Social Science Research 3(4):52-57

Onyekweodiri N.E. \& Agbo A.D. (2015). Utilisation of library resources by veterinary medicine students in two federal universities in South-East Zone of Nigeria.Global Journal of HumanSocial Science: H Interdisciplinary, 15(2): 52-57

Otolo, P.U., Saibakumo, W.T. \& Urhibo, E. (2018). Impact of ICT skills on the use of electronic resources by undergraduate students in Nigerian university libraries. The Information Technologist:an

International Journal Information and Communication Technology

(ICT), 15(1):65-74

Quadri G.U., Adetimirin A.E. \& Idowu O.A. (2014). A study of availability and utilisation pf library electronic resources by undergraduate students in private universities in Ogun State Nigeria. International Journal of Library and Information Science, 6(2): 28-34

Rosenita I. and Zainab A.N. (2013). The pattern of e-book use amongst undergraduates in Malaysia: a case of to know is to use. Arxiv preprint arxiv: 1301.5400

Sinha, M. I. (2012). Internet literacy skills and Internet usage patterns to access eresources by Assam University Library Users: an evaluative study. International Research Journal of Library, Information and Archival Studies, 2(1): 1026.

Ukaegbu, B.C.N. \& Wegwu. B.J. (2019). Accessing library resources for ICT skill acquisition in Nigerian universities for ICT skill acquisition in Nigeriam universities. The Information Technologist:an International Journal Information and Communication Technology (ICT),16(1): 203-209 